ISSN 1420-3049

www.mdpi.com/journal/molecules

Article

\title{
Alkaloids from Fissistigma latifolium (Dunal) Merr.
}

\author{
Asmah Alias ${ }^{1}$, Hazrina Hazni ${ }^{2}$, Faridahanim Mohd Jaafar ${ }^{1}$, Khalijah Awang ${ }^{2}$ and \\ Nor Hadiani Ismail ${ }^{1, *}$
}

1 Faculty of Applied Sciences, Universiti Teknologi Mara, 40450 Shah Alam, Selangor, Malaysia

2 Department of Chemistry, Universiti Malaya, Kuala Lumpur, Malaysia

* Author to whom correspondence should be addressed; E-Mail: norhadiani@salam.uitm.edu.my; Tel.: 03-55444591.

Received: 1 June 2010 / Accepted: 7 June 2010 / Published: 24 June 2010

\begin{abstract}
A phytochemical study of the bark of Fissistigma latifolium (Annonaceae) yielded a new aporphine alkaloid, (-)- $N$-methylguattescidine (1), and eight known alkaloids: liriodenine (2), oxoxylopine (3), (-)-asimilobine (4), dimethyltryptamine (5), (-)remerine (6), (-)-anonaine (7), columbamine (8) and lysicamine (9). The compounds were isolated using various chromatographic methods and structural elucidation was accomplished by means of spectroscopic methods, notably $1 \mathrm{D}-\mathrm{NMR}\left({ }^{1} \mathrm{H},{ }^{13} \mathrm{C}\right.$, DEPT), 2DNMR (COSY, HMQC, HMBC), UV, IR and MS.
\end{abstract}

Keywords: Fissistigma latifolium; Annonaceae; alkaloids

\section{Introduction}

Fissistigma latifolium (Dunal) Merr. from the genus Fissistigma is a climbing shrub found in low land forest of Malaysia, Sumatra, Borneo and Philippines [1]. The genus Fissistigma (Annonaceae) consists of about 80 species and is widely distributed in Asia and Australia [2]. Our previous studies on F. fulgens and F. manubriatum have resulted in the isolation of aporphine, oxoaporphine and protoberberine alkaloids [3,4]. In this paper, we report the isolation and characterization of a new aporphine alkaloid, (-)- $N$-methylguattescidine (1), from $F$. latifolium. This alkaloid, together with eight known alkaloids, namely liriodenine (2), oxoxylopine (3), (-)-asimilobine (4), dimethyltryptamine (5), (-)-remerine (6), (-)-anonaine (7), columbamine (8) and lysicamine (9), were obtained from the methanol extract of the bark of the plant. 
Figure 1. Alkaloids 1-9, isolated from Fissistigma latifolium.
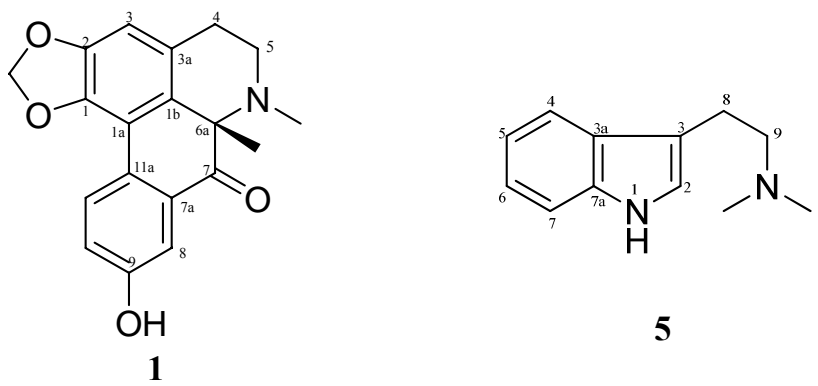<smiles>COc1cc2c(cc1O)-c1cc3ccc(OC)c(OC)c3c[n+]1CC2</smiles>

8<smiles></smiles><smiles>[R]c1cc2c3c(c1[R2])-c1ccccc1CC3N([R3])CC2</smiles>

$\begin{array}{ccc} & \mathrm{R}_{1}+\mathrm{R}_{2} & \mathrm{R}_{3} \\ \mathbf{2} & \mathrm{OCH}_{2} \mathrm{O} & \mathrm{H} \\ \mathrm{OCH}_{2} \mathrm{O} & \mathrm{OCH}_{3}\end{array}$ $\begin{array}{lcc} & \mathrm{R}_{1}+\mathrm{R}_{2} & \mathrm{R}_{3} \\ \mathbf{6} & \mathrm{OCH}_{2} \mathrm{O} & \mathrm{CH}_{3} \\ 7 & \mathrm{OCH}_{2} \mathrm{O} & \mathrm{H}\end{array}$<smiles>COc1c(O)cc2c3c1-c1ccccc1CC3NCC2</smiles><smiles>COc1cc2ccnc3c2c(c1OC)-c1ccccc1C3=O</smiles>

\section{Results and Discussion}

(-)- $N$-Methylguattescidine (1) exhibited a molecular formula of $\mathrm{C}_{19} \mathrm{H}_{17} \mathrm{O}_{4} \mathrm{~N}$ based on the HRESIMS spectrum (positive mode), which showed a pseudomolecular ion at $\mathrm{m} / \mathrm{z} 324.3581[\mathrm{M}+\mathrm{H}]^{+}$(calcd. 324.3595). The UV spectrum showed an absorption band at $310 \mathrm{~nm}$, suggesting the compound was an aporphine alkaloid with substitutions at position 1 and 2 [5]. The IR spectrum indicated the presence of a $\mathrm{C}=\mathrm{O}$ band at 1,710 and an $\mathrm{OH}$ one at $3,409 \mathrm{~cm}^{-1}$. The ${ }^{13} \mathrm{C}-\mathrm{NMR}$ spectrum showed presence of 19 carbons. The signal at $\delta 198.0 \mathrm{ppm}$ confirmed the presence of the carbonyl group, while the signal at $\delta$ $153.1 \mathrm{ppm}$ is evidence for the oxygenated aromatic carbon. The DEPT spectrum revealed three methylene carbons at $\delta 26.9 \mathrm{ppm}, 41.4 \mathrm{ppm}$ and $96.9 \mathrm{ppm}$. Signal at $\delta 96.9 \mathrm{ppm}$ is indicative of a methylenedioxy carbon. This is consistent with two doublets at $\delta 5.99 \mathrm{ppm}(J=1.2 \mathrm{~Hz})$ and $\delta$ $6.07 \mathrm{ppm}(\mathrm{J}=1.2 \mathrm{~Hz})$ in the ${ }^{1} \mathrm{H}-\mathrm{NMR}$ spectrum for the protons of methylenedioxy group which is typically located at positions 1 and 2 . The characteristic ABD aromatic signals of H-11, H-10 and H-8 of aporphine alkaloid were observed at $\delta 8.24 \mathrm{ppm}(d, J=8.7 \mathrm{~Hz}), \delta 7.13 \mathrm{ppm}(d d, J=8.7,2.7 \mathrm{~Hz})$ and $\delta 7.39 \mathrm{ppm}(d, J=2.7 \mathrm{~Hz})$, respectively. The singlet at $\delta 6.54 \mathrm{ppm}$ is due to $\mathrm{H}-3$ while two methylene signals at position 4 and 5 appeared as multiplets between $\delta 3.01-2.55 \mathrm{ppm}$. Assignment of 
C-4 at $\delta 26.9$ ppm was made based on the HMQC correlations to H-4 ( $\delta 2.55 \mathrm{ppm})$ and H-4' ( $\delta$ $3.00 \mathrm{ppm})$. Similarly, C-5 at $\delta 41.4 \mathrm{ppm}$ showed correlation to H-5 ( $\delta 2.99 \mathrm{ppm})$ and H-5' $(\delta$ $3.01 \mathrm{ppm})$. The ${ }^{1} \mathrm{H}-\mathrm{NMR}$ spectrum also exhibited an $N$-methyl signal at $\delta 2.34 \mathrm{ppm}$ and another methyl group attached to C-6a gave a singlet at $\delta 1.52 \mathrm{ppm}$. The assignment of this methyl group at the 6a position is confirmed through its HMBC correlation with C-6a at $\delta 62.7 \mathrm{ppm}, \mathrm{C}-1 \mathrm{~b}$ at $\delta 118.3 \mathrm{ppm}$ and C-7 at $\delta 198.0 \mathrm{ppm}$. The quaternary carbon signals were assigned based on HMBC experiment. C1a at $\delta 108.9 \mathrm{ppm}, \mathrm{C}-7 \mathrm{a}$ at $\delta 126.0 \mathrm{ppm}$ and $\mathrm{C}-9$ at $\delta 153.1 \mathrm{ppm}$ were assigned based on their correlations with $\mathrm{H}-11$ at $\delta 8.24 \mathrm{ppm}$, while $\mathrm{C}-1 \mathrm{~b}$ at $\delta 118.3 \mathrm{ppm}$ and $\mathrm{C}-2$ at $\delta 143.2 \mathrm{ppm}$ showed correlations with $\mathrm{H}-3$ at $\delta 6.54$ ppm. Table 1 summarizes the ${ }^{1} \mathrm{H}$ - and ${ }^{13} \mathrm{C}-\mathrm{NMR}$ data of compound $\mathbf{1}$.

Table 1. ${ }^{1} \mathrm{H}-\mathrm{NMR}(300 \mathrm{MHz})$ and ${ }^{13} \mathrm{C}-\mathrm{NMR}(75 \mathrm{MHz})$ spectral data of compound 1 in $\mathrm{CD}_{3} \mathrm{OD}(\delta$ in ppm, $J$ in $\mathrm{Hz})$.

\begin{tabular}{|c|c|c|c|}
\hline Position & ${ }^{1}$ H-NMR ( $\delta$ ppm) & ${ }^{13} \mathrm{C}-\mathrm{NMR}(\delta \mathrm{ppm})$ & HMBC \\
\hline 1 & - & 138.8 & \\
\hline $1 \mathrm{a}$ & - & 108.9 & \\
\hline $1 b$ & - & 118.3 & \\
\hline 2 & - & 143.2 & \\
\hline 3 & $6.54, s$ & 103.9 & $\mathrm{C}-1 \mathrm{~b}, \mathrm{C}-1, \mathrm{C}-2$ \\
\hline $3 a$ & - & 125.3 & \\
\hline 4 & $2.55,3.00, m$ & 26.9 & \\
\hline 5 & $2.99,3.01, m$ & 41.4 & \\
\hline $6 a$ & - & 62.7 & \\
\hline 7 & - & 198.0 & \\
\hline $7 \mathrm{a}$ & - & 126.0 & \\
\hline 8 & $7.39, d,(J=2.7 \mathrm{~Hz})$ & 110.3 & C-9, C-7 \\
\hline 9 & - & 153.1 & \\
\hline 10 & $7.13, d d,\left(J_{o}=8.7 \mathrm{~Hz}, J_{m}=2.7 \mathrm{~Hz}\right)$ & 122.2 & $\mathrm{C}-11 \mathrm{a}$ \\
\hline 11 & $8.24, \mathrm{~d},(J=8.7 \mathrm{~Hz})$ & 122.7 & C-1a, C-7a, C-9 \\
\hline 11a & $3.52, m$ & 123.1 & \\
\hline $\mathrm{O}-\mathrm{CH}_{2}-\mathrm{O}$ & $5.99,6.07, d,(J=1.2 \mathrm{~Hz})$ & 96.9 & $\mathrm{C}-1, \mathrm{C}-2$ \\
\hline $\mathrm{N}-\mathrm{CH}_{3}$ & $2.34, s$ & 34.1 & C-6a \\
\hline $\mathrm{CH}_{3}$ & $1.52, \mathrm{~s}$ & 25.0 & C-6a, C-1b, C-7 \\
\hline
\end{tabular}

Based on all spectroscopic data compound 1 was identified as (-)- $N$-methylguattescidine, a new 6amethylated-7-oxo-aporphine alkaloid. Occurrence of 6a-methylated aporphine alkaloids is very rare, having only been previously reported by Reynald et al. [6]. Apart from the $\mathrm{N}_{-} \mathrm{CH}_{3}$ signal at $\delta$ $2.34 \mathrm{ppm}$, the signals of all other protons in compound $\mathbf{1}$ are in a good agreement with that of guattescidine. The slight differences in the chemical shifts may be contributed to the different solvents used for the NMR measurement. The optical rotation of all known isolated compounds were found to be (-ve) thus corresponding to $\beta$ configuration [7]. Therefore, based on biogenetic reasoning, the configuration at C-6a for (-)- $N$-methylguattescidine is deduced to be $\beta$.

Other isolated compounds from this plant are three aporphine alkaloids, (-)-asimilobine, (-)anonaine and (-)-remerine; three oxoaporphine alkaloids, liriodenine, oxoxylopine and lysicamine; one tryptamine alkaloid, dimethyltryptamine and one protoberberine alkaloid, columbamine. These compounds were characterized based on analysis of spectroscopic data and comparison with literature data. 


\section{Experimental}

\subsection{General}

The ${ }^{1} \mathrm{H}-\mathrm{NMR}$ and ${ }^{13} \mathrm{C}-\mathrm{NMR}$ were recorded in $\mathrm{CDCl}_{3}$ and $\mathrm{CD}_{3} \mathrm{OD}$ on a Bruker 300 Ultrashield NMR spectrometer measured at 300 and $75 \mathrm{MHz}$. Chemical shifts are reported in ppm and $\delta$ scale and the coupling constants are given in Hz. Melting points were taken on a hot stage Gallen Kamp melting point apparatus with microscope and were uncorrected. The infrared (IR) was recorded on a Perkin Elmer spectrum one FT-IR spectrometer using $\mathrm{CH}_{2} \mathrm{Cl}_{2}$ as solvent. Optical rotations were measured on a JASCO P1020 digital polarimeter. HRESIMS was obtained on a Thermo Finnigan Automass Multi. The ultraviolet (UV) spectra were obtained in ethanol on a Shimadzu UV-Vis 160i instrument.

\subsection{Plant material}

The bark of Fissistigma latifolium (Dunal) Merr. (KL 4623) was collected from Dungun, Terengganu and was identified by L.E. Teo (Department of Chemistry, University of Malaya) and all plant materials were screened for their alkaloidal content before any chemical analysis. Voucher specimens were deposited at the Herbarium, Department of Chemistry, University of Malaya.

\subsection{Extraction and isolation of the alkaloids}

Dried and ground bark of F. latifolium $(1 \mathrm{~kg})$ was defatted with petroleum ether $(5 \mathrm{~L})$ overnight before being extracted with dichloromethane $(7.5 \mathrm{~L})$ and methanol $(10 \mathrm{~L})$ for eight hours using a Soxhlet extractor. The methanol extract was subjected to acid-base extraction. The crude alkaloids $(3.5 \mathrm{~g})$ from the $\mathrm{MeOH}$ extract were subjected to SPE flash column using a gradient elution system of hexane (hex):ethyl acetate (EA) and dichloromethane (DCM):methanol (MeOH) to give 29 fractions. The combined fractions 19-20 were subjected to PTLC using a 95:5 DCM:MeOH solvent system to yield a mixture of compounds $2(15.3 \mathrm{mg})$ and $3(7.0 \mathrm{mg})$ [8,9]. These compounds were separated by repeated PTLC using the same solvent system. Fraction 23 from the SPE column was subjected to PTLC using a 95:5 DCM:MeOH solvent system to obtain compounds 4 (5.2 mg) and 5 (5.7 mg) $[10,11]$. The combined fractions 26 and 27 from the SPE were subjected to column chromatography using a gradient elution system of hex:EA and DCM:MeOH to obtain 13 fractions. Fractions 7-10 were combined and subjected to PTLC using a 93:7 DCM:MeOH solvent system to yield compounds 6 $(6.4 \mathrm{mg})$ and $7(8.2 \mathrm{mg})[12,13]$. The combined fractions 11-13 were subjected to PTLC using a 90:10 DCM:MeOH solvent system to obtain alkaloid $1(5.1 \mathrm{mg})$. Fraction 29 from the SPE was subjected to PTLC using a 90:10 DCM:MeOH solvent system to yield compounds 8 (4.6 mg) and 9 (3.9 mg) $[14,15]$. Spectral data for compounds 2-9 were in agreement with published data [8-15].

(-)-N-Methylguattescidine (1). yellow amorphous solid; $[\alpha]_{D}^{30}:-20^{\circ}\left(\mathrm{c}=0.1 \mathrm{mg} \mathrm{mL}{ }^{-1}, \mathrm{CHCl}_{3}\right) ; \mathrm{MS} \mathrm{m} / \mathrm{z}$ : 324.1242, $\mathrm{C}_{19} \mathrm{H}_{17} \mathrm{O}_{4} \mathrm{~N}$; UV $\lambda_{\max }$ nm EtOH: 235, 310; IR $v_{\max } \mathrm{cm}^{-1}: 3409,1710,1266 ;{ }^{1} \mathrm{H}-\mathrm{NMR}$ and ${ }^{13} \mathrm{C}$ NMR data, see Table 1. 


\section{Conclusions}

The phytochemical study on the bark of Fissistigma latifolium (Annonaceae) yielded a new aporphine alkaloid, (-)- $N$-methylguattescidine (1), and the eight known alkaloids liriodenine (2), oxoxylopine (3), (-)-asimilobine (4), dimethyltryptamine (5), (-)-remerine (6), (-)-anonaine (7), columbamine (8) and lysicamine (9). Tryptamine alkaloids have never been reported from Fissistigma species, whereas the new compound (-)- $N$-methylguattescidine (1) represents a rare finding of a naturally occurring 6a-methylated-7-oxo-aporphine alkaloid.

\section{Acknowledgements}

The authors thank Universiti Teknologi MARA and Universiti Malaya for research support and facilities. Asmah Alias thanks Ministry of Science, Technology and Innovation, Malaysia for scholarship awarded to conduct this work.

\section{References and Notes}

1. Verdout, B. Annonaceae, Flora of Tropical East Africa; Crown Agents for Oversea Government and Administrations: London, UK, 1976; pp. 101-102.

2. Sinclair, J. A revision of the Malayan Annonaceae. The Gardens' Bulletin Singapore 1955, 14, 149-169.

3. Awang, K.; Hamid, A.; Hadi, A. Protoberberine Alkaloids From Fissistigma fulgens Merr. (Annonaceae). Malaysian J. Sci. 2000, 19, 41-44.

4. Saaid, M.; Awang, K. Alkaloids of Fissistigma manubriatum. Malaysian J. Sci. 2005, 24, 41-45.

5. Cordell, G.A. Introduction to Alkaloid: A Biogenetic Approach; John Wiley \& Sons: New York, NY, USA, 1981; pp. 6-19.

6. Reynald, H.; Sabine, R.; Andre, C. Guattescine and Guattescidine, New Aporphine Alkaloids from Guatteria scandens. Tetrahedron 1982, 38, 911-915.

7. Kametani, T. The Chemistry of the Isoquinoline Alkaloids; Tokyo Hyrokawa: Amsterdam, The Netherlands, 1969; p. 275.

8. Tetsuji, K.; Hirofumi, T.; Masataka, I. Liriodenine from Talauma Mexicana. Phytochemistry 1975, 14, 1884-1885

9. Crabb, T.A. Nuclear Magnetic Resonance of alkaloids. In Annual Reports on NMR Spectroscopy; Academic Press: Hampshire, UK, 1975; Volume 6, Part 1, pp. 249-387.

10. Sheng, T.L.; Yang, C.W.; Shiow, P.L. Alkaloids of formosan Fissistigma and Goniothalamus species. Phytochemistry 1985, 24, 1829-1834.

11. Mandel L.R.; Prasad R.; Lopez-Ramos B.; Walker R.W. "The biosynthesis of dimethyltryptamine in vivo". Res. Commun. Chem. Pathol. Pharmacol. 1977, 16, 47-58.

12. Manske, R.H.F. The aporphine alkaloids. In The Alkaloids: Chemistry and Physiology, Chapter 30; Academic Press INC: New York, NY, USA, 1965; Volume 4, pp. 119-145.

13. Bhakuni, D.S. Shobha Tewari, M. Dhar, M. Aporphine alkaloids of Annona squamosa. Phytochemistry 1972, 11, 1819-1822. 
14. Yi, C.C; Fang, R.C.; Chao, M.L; Yang, C.W. Protoberberine alkaloids from Fissistigma balansae. Phytochemistry 1998, 48, 367-369.

15. Akasu, M.; Itokawa, H.; Fujita, M. Oxoaporphine alkaloids from the callus tissue of Stephania cepharantha. Phytochemistry 1975, 14, 1673-1674.

Sample Availability: Samples of the compounds reported in this paper are available from the authors.

(C) 2010 by the authors; licensee MDPI, Basel, Switzerland. This article is an Open Access article distributed under the terms and conditions of the Creative Commons Attribution license (http://creativecommons.org/licenses/by/3.0/). 